\title{
Stone masonry walls and woodworks as architectural heritages in rural areas of the Eastern Anatolia Region, Turkey: case studies from Erzurum, Kars and Ardahan
}

\author{
D. G. Yilmaz \\ School of Planning, Architecture and Civil Engineering, \\ Queen's University Belfast, UK
}

\begin{abstract}
The land of Turkey has hosted various civilizations throughout history, and it has diverse architectural heritages left from these civilizations. Rural areas and settlements can be seen as the pure reflection of geographical and cultural environment as well as historical and economical. However, today as a consequence of modernisation, the traditional architectural pattern in the rural settlements of Turkey faces the danger of uniformity. There is little interest in documenting and maintaining the civilian architectural heritages in rural settlements. To this end, this research aims to investigate how the construction practice has changed, and affected the continuity of traditional civilian architectural heritages in rural settlements of Turkey. This paper presents direct observations of the researcher from the region selected.
\end{abstract}

Keywords: civilian traditional architectural heritage, rural areas, Turkey, Erzurum, Ardahan, Kars.

\section{Introduction}

The land of Turkey has hosted various civilizations throughout the history, thus it has a diverse cultural and distinctive architectural heritages left from these civilizations. Most of these heritages are touristic attraction sites today, as in many other countries, and most of them either sacred or administration or army buildings, and their ruins. For example, according to the World Heritage list of UNESCO [1] nearly 20 per cent of the heritages are classified as religious places. 
This can be explained by their spiritual importance for the society and their symbolic value for the culture. Therefore, these types of heritages are usually kept under conservation and maintained by local or national authorities, based on their original features. However, it should be noted that the architectural characteristics of such qualified heritage are quite different from the civilian heritages.

Basically, rural areas and settlements can be seen as the pure reflection of geographical and cultural environment as well as historical and economical. From the settlement types and layouts to the house plans and its look, rural areas have their original physical patterns. They are not in the flow with mainstream architectural changes, but not totally isolated either. The dwellers of such settlements tend to modify their built environment according to their needs, or it happens as a must after occurrence of a natural disaster in the area.

Earthquakes are the most destructive natural disaster in Turkey, and when they occur in the rural areas of the country, they cause devastation in the settlements. In such cases, rural dwellers rebuild their built environment with the help of the state. However, they start to perceive their traditional construction practice as vulnerable, so they alter the structural materials they use, and the way they build their shelters. Furthermore, the state also runs regeneration projects in the rural areas affected by an earthquake. As a consequence of all these alterations and regenerations, the traditional architectural heritage in rural areas of Turkey started to vanish in the last decades.

In broader extent, natural disasters are not the only reason behind these changes, but misunderstanding the idea of modernization by the rural communities also cause to lose the rural settlements their uniqueness. Today, the supplement chain for particular structural materials, such as concrete, are so expanded over the country that even in a quite remote area, these materials can be obtained. As a consequence, the traditional architectural pattern desperately faces the danger of uniformity of the rural settlements.

Many researchers and organisations are generally interested in the qualified architectural heritages of rural areas. In contrast, there is little interest in documenting and maintaining the civilian architectural heritages in rural settlements. To this end, in July 2012 a field trip was conducted in eastern Turkey as part of a doctoral study, which aimed to investigate how the construction practice has changed, and affected the continuity of traditional civilian architectural heritages. This paper presents direct observations of the researcher, and aims to contribute documenting and extending the knowledge about the region selected.

\section{Case studies}

Due to the lack of written resources about the traditional civilian architectural heritages in eastern Turkey, the researcher selected the Eastern Anatolia Region of Turkey as the focus area of this study. Three provinces of the region, which are Erzurum, Kars and Ardahan, were selected as the case studies due to having their characteristic housing types in their rural settlements (fig. 1). 


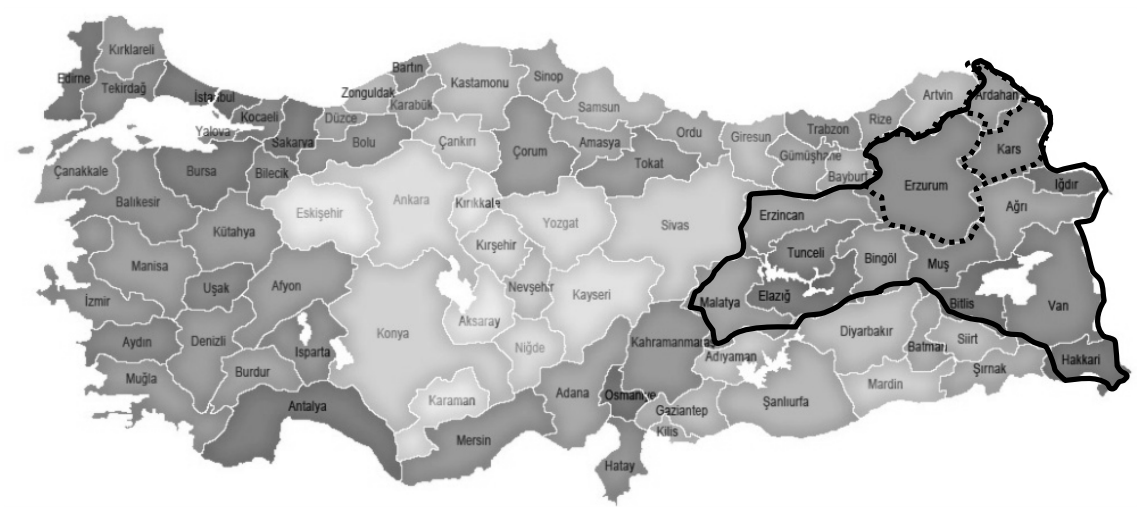

Figure 1: $\quad$ The map of Turkey, the black bold line shows the Eastern Anatolia Region, and the black dotted-lines show the provinces selected for this study.

Case study, as a qualitative method, is a suggested strategy when the researcher has little or no control over the events within real life context [2]. In order to collect transferable data from the field, explorative multiple-case study approach was adopted. The data collection was started from Erzurum, and followed by Ardahan, and ended in Kars. In total 50 rural settlements were visited in all three provinces, and field trip was completed in nine days.

Normally, civilian architectural practice in these areas is based on local materials and their different configurations. Rubble or cut stone, round or shaped timber for roof, supportive lumber in walls, earth filled roof and mud mortar are local structural materials used in the area. However, these materials are accepted as low strength and poor quality under any seismic motions, due to collapsing and causing life losses in rural areas. Since the natural disasters are effective on the trend of construction practice, it is important to mention the earthquakes occurred in the area selected over the last century. The frequency of the earthquakes as shown in Table 1 proves that the area is situated on a seismically active zone, and prone to have earthquakes in future.

Table 1: The dates of earthquakes occurred in Kars and its adjacent areas [3].

\begin{tabular}{|c|c|}
\hline $13^{\text {th }}$ May 1924 & $19^{\text {th }}$ May 1938 \\
\hline $6-8-13^{\text {th }}$ September 1924 & $14^{\text {th }}$ November 1938 \\
\hline $9^{\text {th }}$ January 1925 & $17^{\text {th }}$ April 1940 \\
\hline $12^{\text {th }}$ February 1925 & $5^{\text {th }}$ January 1941 \\
\hline $13^{\text {th }}$ May 1925 & $16^{\text {th }}$ April 1941 \\
\hline $22-23^{\text {rd }}$ October 1926 & $25^{\text {th }}$ March 1976 \\
\hline $1^{\text {st }}$ May 1935 & $30^{\text {th }}$ October 1983 \\
\hline $26^{\text {th }}$ March 1936 & $7^{\text {th }}$ December 1988 \\
\hline
\end{tabular}




\subsection{The case study of Erzurum}

The province of Erzurum has the largest area among the other provinces of Turkey. It has approximately 1900 metres of altitude [4], and today 63\% of its total population live in the urban areas, while only 37\% in rural [5]. According to Gok and Kayserili [6], between the years of 1935 and 2000 there was a huge internal migration in this province from the rural to urban areas. Table 2 shows the rapid demographic changes of the province, however for the years between 2000 and 2009, it should be noted that the province gave outer migration due to being saturated to internal migration.

Table 2: $\quad$ The proportion of rural and urban settlements in Erzurum.

\begin{tabular}{|c|c|c|c|c|}
\hline \multirow{2}{*}{ Year } & \multicolumn{2}{|c|}{ Urban } & \multicolumn{2}{c|}{ Rural } \\
\cline { 2 - 5 } & $\%$ & Population & $\%$ & Population \\
\hline $1935[6]$ & 12 & 46.000 & 88 & 340.000 \\
\hline $1955[6]$ & 21 & 110.000 & 79 & 412.000 \\
\hline $1980[6]$ & 35 & 285.000 & 65 & 516.000 \\
\hline $2000[6]$ & 60 & 560.000 & 40 & 377.000 \\
\hline $2009[5]$ & 63 & 490.000 & 37 & 283.000 \\
\hline
\end{tabular}

Erzurum has its characteristic and traditional civilian architecture, however today this practice is rarely continued by rural dwellers. The roof style of this sample of architecture is called 'kırlangıç örtü' (kırlangıç covering), and it covers either living room or baking room of the traditional rural houses (fig. 2). Normally, rectangular shaped timber elements are used to build this traditional roof.
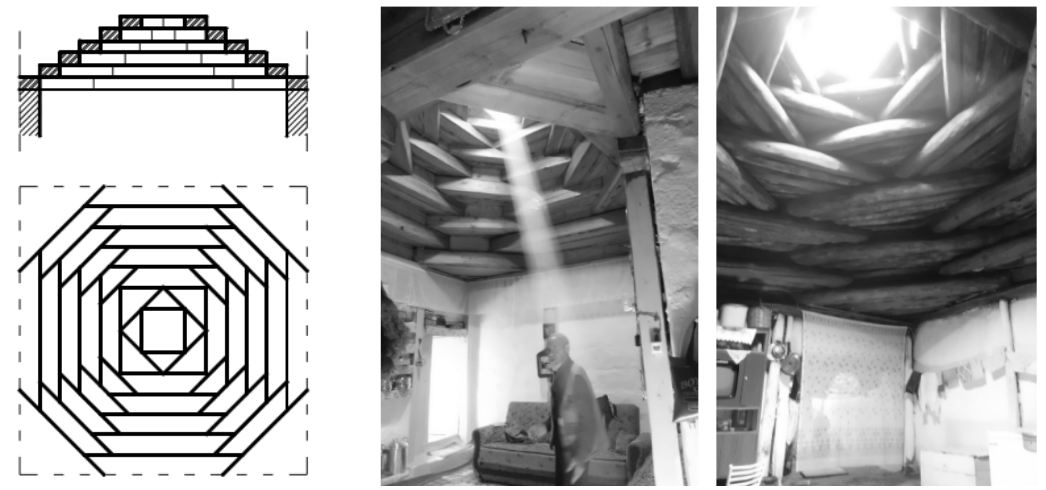

Figure 2: The section and plan of 'kırlangıç örtü' [7], and its interior view from dwellers' houses who maintained it; the example of rectangular shaped timber elements (in the middle), and the example of round timber elements (on the right), both use the space as their living room (photos taken by the author). 
However, in case of aiming to cover larger spaces, round timber is also used. These timber elements are placed on top of each other as diagonal, and it creates octagonal shape, which ends with a square shape at the top of the roof. This square shaped space is used without glass in order to ventilate the room. Today, due to requiring craftsmanship to build such an example, thus its high cost, this civilian architectural heritage can only be observed in few houses.

There is also another type of roof style, which is used for covering larger spaces. In this type, timber is kept as raw material with its round shape, but the roof system has its typical configuration. Today, this roof type is generally used to cover barns (fig. 3).

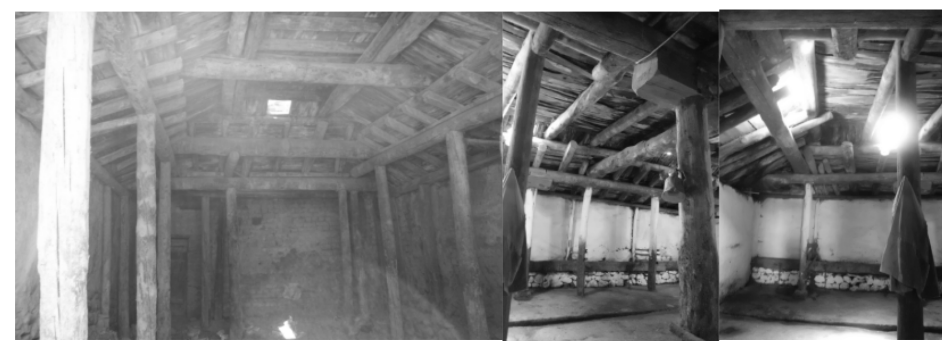

Figure 3: The interior view from a dweller's barn, which was built according to traditional construction practice (photos taken by the author).

Like in much rural architecture in world countries, stone is the material the most used in the traditional architectural heritage of rural Erzurum. The rural houses can be single or two-storey buildings, and for walling, every kind of shaped stone were used in these houses. Generally, large cut stones were placed at the corners, while rubble or small sizes of cut stones were used to fill the wall. However, today most of them became ruins due to being left unoccupied (fig. 4). Some owners migrated, while some built a new house with non-local materials.
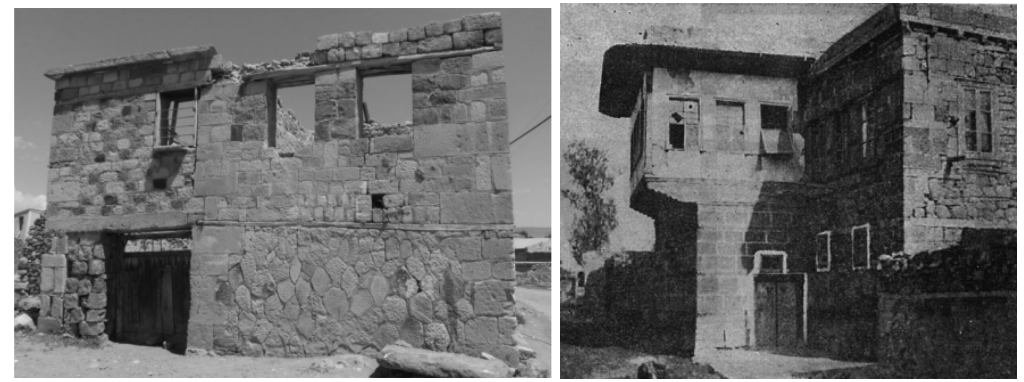

Figure 4: The exterior wall of a traditional house, which is a ruin today, on the left (photos taken by the author), and an old picture of these traditional architectural heritage from the year of 1947, on the right [8]. 


\subsection{The case study of Ardahan}

Ardahan was under the same administration body with Kars until 1992, the year it was separated from Kars as district and became a province with six districts. According to the census in 2011 [5], it has the smallest population in the country, nearly 108,000 , and $65 \%$ of this population live in rural areas, while only $35 \%$ in urban. It has approximately 3000 metres of altitude [4], thus the settlements are situated on mountainous areas and generally far from each other. Ardahan is the north-eastern border of Turkey, and neighbour to Georgia. The district of Gole is the largest one in Ardahan, and its central area is closer to Kars. This short distance to Kars affected the route of the field trip since the cost and time were limited for the completion of this study. Due to the lack of documentation for the traditional architectural heritage in the area, it is not possible to present either a background for the materials or the structural type of the civilian buildings. However, it can be strongly stated that the civilian architecture had characteristics in woodworks of the houses (fig. 5).

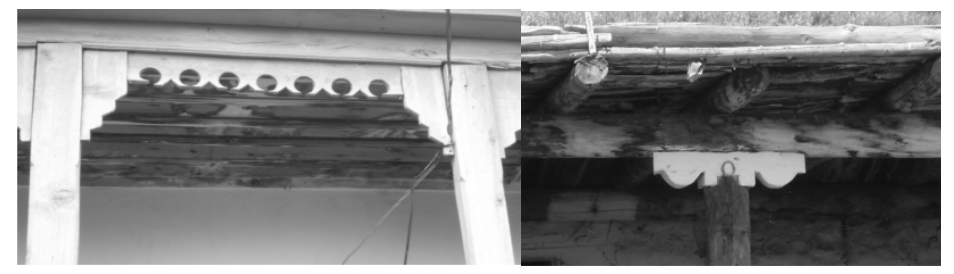

Figure 5: The examples of woodworks applied to the post-head for terrace roof (photos taken by the author).

Besides, timber is still in use when building the roof of a house. There are examples of round and rectangular shaped timber in the houses visited. Some families maintained their houses or renewed materials as much as they can afford, which is worth appreciating (fig. 6).

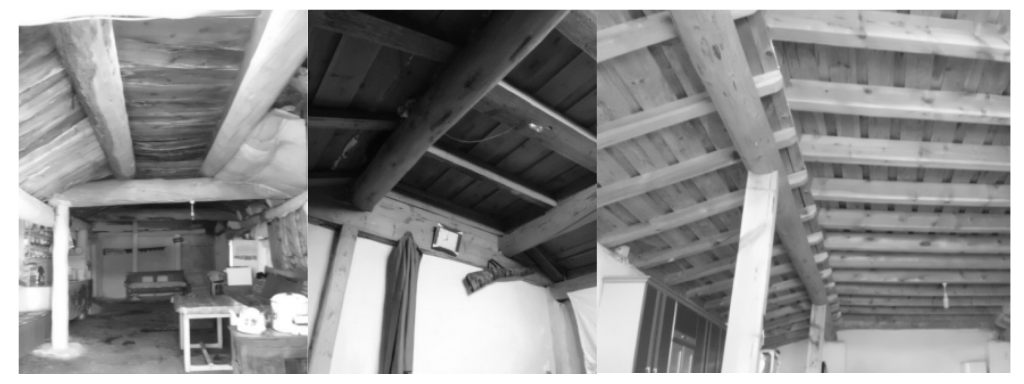

Figure 6: The interior views of round timber used for roof, the left and middle; an example of renewed rectangular shaped timber for roof from a dweller's house (photos taken by the author). 
During the field trip, various walling types were observed, thus it is difficult to state which was the genuine architectural practice of the area. However, rubble stone were often used than cut stone. This might be related to the proximity of Kars and their historical bond, which cause to see similar architectural traces in the area (fig. 7).

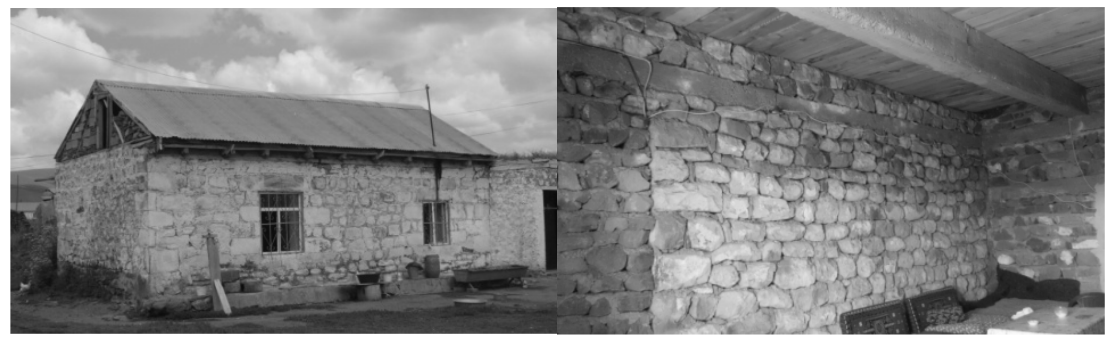

Figure 7: The exterior view of a maintained house with rubble stone wall, on the left; the interior view of a renewed rubble stone wall, on the right (photos taken by the author).

\subsection{The case study of Kars}

Kars is another north-eastern border of Turkey, and neighbour to Armenia. It has altitude of nearly 1800 metres [4], but it is not as mountainous as Ardahan and Erzurum. The settlements are generally situated on plateaus. Total population is approximately 305.000 according to the census in 2011 [5], and 57\% of this population live in the rural areas, while $43 \%$ in urban. Kars has eight districts and over 70 villages.

Because, Kars was under the sovereignty of Russia over 40 years, it has significant and qualified traditional Russian architectural heritages. Today, many of these heritages were documented and registered and kept under conservation. Particularly, the city centre area host many of these qualified examples [9]. Although, the typical wall material of the qualified heritage is the cut-basalt stone, this walling type can also be observed in the civilian architectural practice of rural settlements in Kars, which were built with cut-stones locally available (fig. 8).

Timber usage has similar types with the examples from Ardahan and Erzurum. It should be noted as well that some houses became ruins due to being left by the owners, while some dwellers maintained their houses as possible as they can (fig. 9). They, fortunately, mentioned that they knew the distinction of the civilian architectural practice in the area, thus they see their shelters as valuable to keep up.

However, a large number of unoccupied and damaged buildings might be the consequence of the earthquakes in the history of the area, as well as the migration problem. 


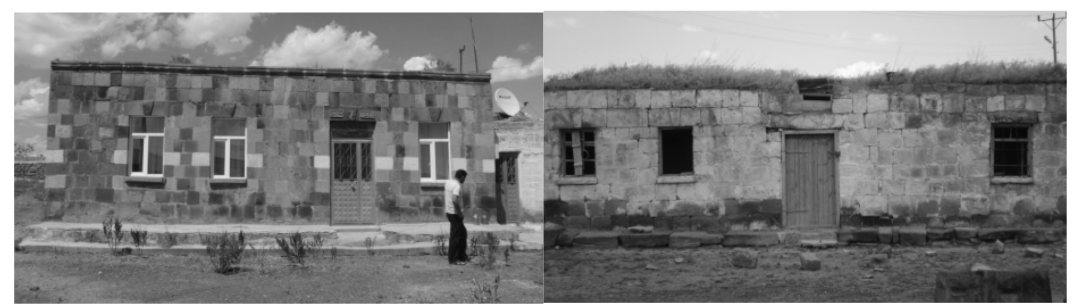

Figure 8: The exterior view of a maintained house with cut-stone wall, on the left; an unoccupied house with cut-stone wall, on the right (photos taken by the author).

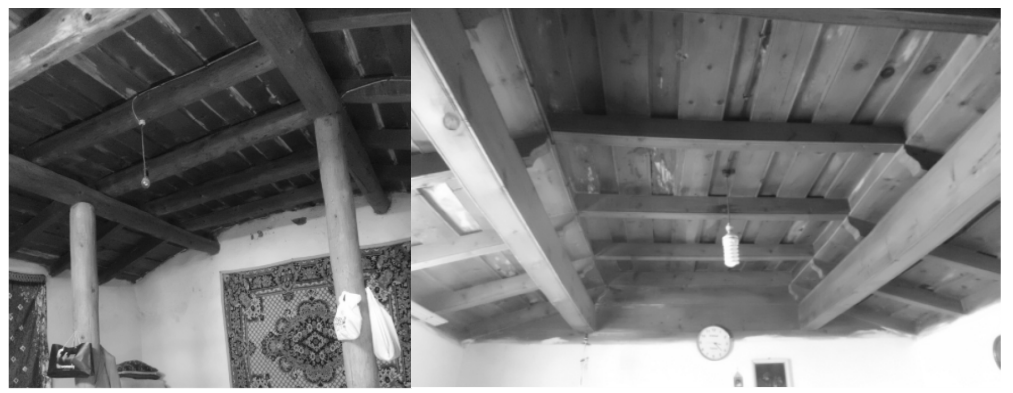

Figure 9: The interior view of a maintained roof with round timber elements, on the left; an example of renewed roof with rectangular timber, on the right (photos taken by the author).

\subsection{The threat of 'modernization' in the rural settlements}

During the field trips, fully and partially examples of traditional civilian architectural heritage were observed in rural settlements of Erzurum, Ardahan and Kars. Although these areas have extensive historical backgrounds, today they started to appear similar to each other due to the supply chain provided for non-local structural materials, such as concrete, steel and aluminium. As a result of easily approaching these materials, and their low prices, rural dwellers started to use and build their shelters with these materials for the last three decades. Such woodworks and stone walling showed in figures of the case studies need craftsmanship, which are hardly found today. Therefore, maintaining the houses or rebuilding the new according to these traditional practices cost more expensive than buying fabricated materials and applying changes by self. This situation generates inevitable results in these rural settlements, which can be called either 'modernisation' or 'uniformity' of the built environment. In the rural settlements visited, there were more examples of such buildings showed in fig. 10, which are called 'hybrid structures' due to being modified with non-local materials. There were also numerous houses built with these materials (fig. 10). 

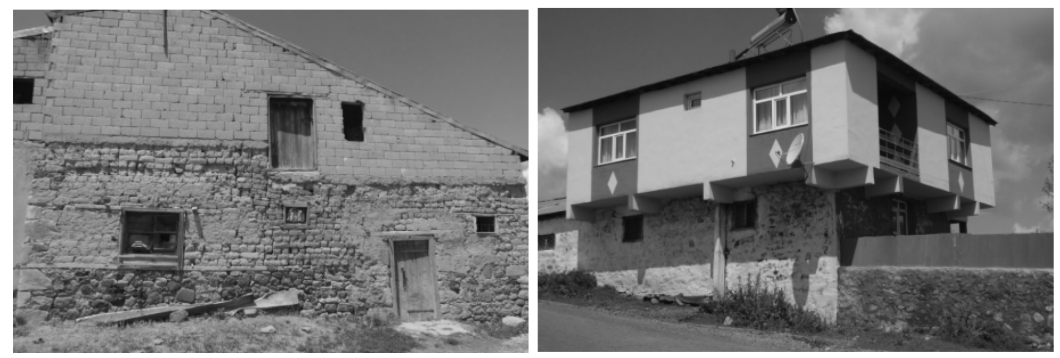

Figure 10: The exterior view of hybrid houses, which were added the second floor with non-local materials, while the walls in ground floor were local materials, samples from Erzurum, on the left, and Ardahan, on the right (photos taken by the author).
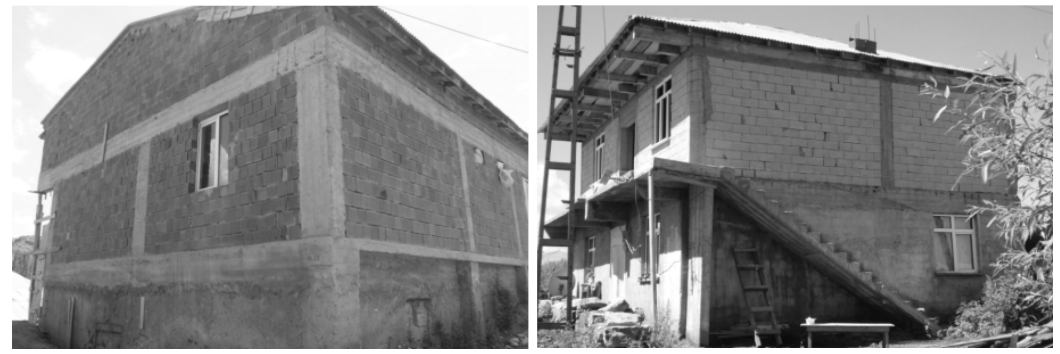

Figure 11: The exterior views of houses built solely with non-local materials, samples from Erzurum, on the left, and Ardahan, on the right (photos taken by the author).

Beside the problem of losing the originality, these settlements start to be vulnerable to future earthquakes. For example, buildings as shown in fig. 10, due to the heavy-weight of the second floors added on adobe brick walls of poor quality, these structures are prone to collapse in a seismic motion. Similarly, even they are built fully with non-local materials, as in fig. 10, due to not being controlled by an engineer or architect, they cannot be considered as earthquakeresistant, which is the common reason behind this change in construction practice.

\section{Conclusion}

Since the entire land of Turkey hosted various civilisations, the existing traditional architectural heritages spread out over the country. Generally, qualified architectural heritages, such as sacred, administration and army buildings, are known and turned into touristic attraction points, which are centrally located. However, there are also various traditional civilian architectural heritages in rural areas of the country. The Eastern Anatolia Region of Turkey has the largest area in the country and covers thousands of rural 
settlements. Unlike qualified architecture, there is a certain lack of architectural knowledge and interest in the civilian heritages in rural areas of this region.

This study was an explorative multiple-case study, which was conducted in the field. For the purpose of contributing to the gap in the knowledge about the civilian architectural heritage of the region, the provinces of Erzurum, Ardahan and Kars were selected. There were the limitations of time and cost to complete the field work. Thus, in total 50 rural settlements were visited and visual data collected both from the buildings and the landscapes.

As a conclusion it can be stated that the settlements have their own civilian architectural heritages depending on their areas. These rural settlements should be kept under control in terms of sustaining the traditional architectural heritage in the area. Otherwise, due to this rapid and degenerative change in construction practice, the samples of civilian traditional architectural heritage will not remain in few decades. Furthermore, the way the residents in the settlements modify or rebuild creates highly vulnerable built environment to earthquakes. To this end, there is an urgent need of preventing these implementations in order to reduce the possible results of earthquake hazards. As a recommendation, more awareness and interest should be raised among the local authorities and researchers in order to sustain the civilian heritages in the built environment; at least they all should be documented and archived for future implementations either by dwellers or the authorities.

\section{References}

[1] UNESCO, whc.unesco.org/en/religious-sacred-heritage/.

[2] Yin, R. K., Case Study Research: Design and Methods, 3rd Edition, SAGE Publications, 2003.

[3] Tekir, S., Earthquakes in Kars and its Surrounding (1924-1941), History Studies, Vol. April, pp. 423-436, 2012.

[4] Wikipedia, en.wikipedia.org.

[5] Turkish Statistical Institute, www.turkstat.gov.tr.

[6] Gok, Y., and Kayserili, A., Rural-Urban Population Change in Erzurum in the Period of Republic, Eastern Geographical Review, Vol. 15, No. 24, pp. 1-18, 2010.

[7] Yildirim, K., and Hidayetoglu, M. L., A Research on the Varieties of the Features and the Construction Techniques of the Wooden Ceiling Decorations at the Traditional Turkish Houses, International Symposium of Traditional Arts, 16-18 ${ }^{\text {th }}$ November, Izmir, Turkey, 2006.

[8] Hotan, H., Mimarlı Etüdleri: Erzurum Evleri, ARKITEKT, Vol. 1-2, pp. 27-30, 1947.

[9] The Ministry of Settlements and Public Works (2011). Kars Kentlesme Yerlesme ve Mekansal Inceleme Raporu. www.kentges.gov.tr/_dosyalar/kiu _kars_mekansal_inceleme_raporu2.pdf. 